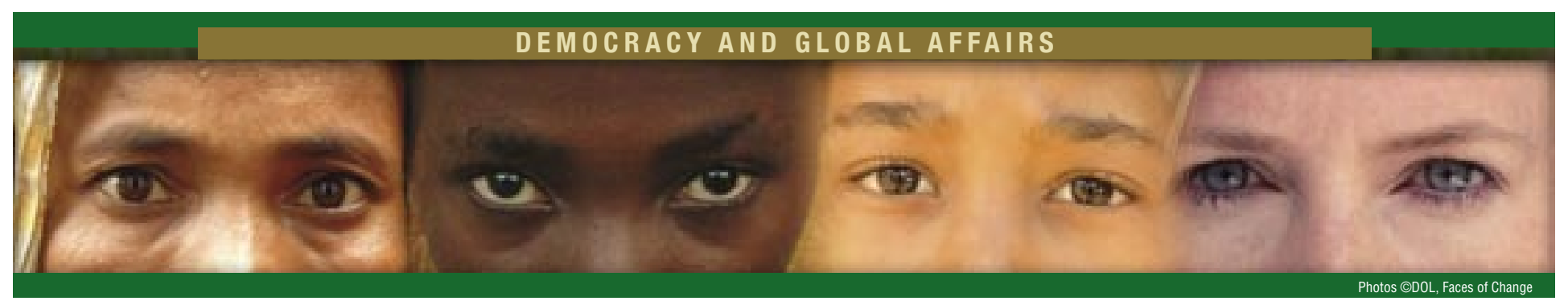

\title{
The Facts About Human TRAFFICKING FOR ForCED LABOR
}

\section{A Victim's Story}

Rajila, age 30, left her home in India to work in Saudi Arabia based on promises of a good salary and free housing from a company that supplies laborers for hospitals. But what seemed like a dream opportunity turned out to be a nightmare. Rajila, together with other foreign women, was forced to work 12 hour shifts, six days a week. She was never paid. The "free" housing was excruciatingly confining, and, when the women returned from work, they were locked in their rooms. Once a week they were escorted to the local market to purchase groceries and other necessities. She and other Muslim laborers from India were not allowed to practice their faith in local mosques. Rajila left Saudi Arabia taking with her no accumulated salary from three and a half years of uninterrupted work. $^{1}$

\section{What is Human Trafficking?}

Trafficking in persons is modern-day slavery. Annually, approximately 600,000 to 800,000 people are trafficked across international borders; millions more are enslaved in their own countries. The common denominator of trafficking scenarios is the use of force, fraud or coercion to exploit a person for commercial sex or for the purpose of subjecting a victim to involuntary servitude, debt bondage, or forced labor. The use of force or coercion can be direct and violent, or psychological.

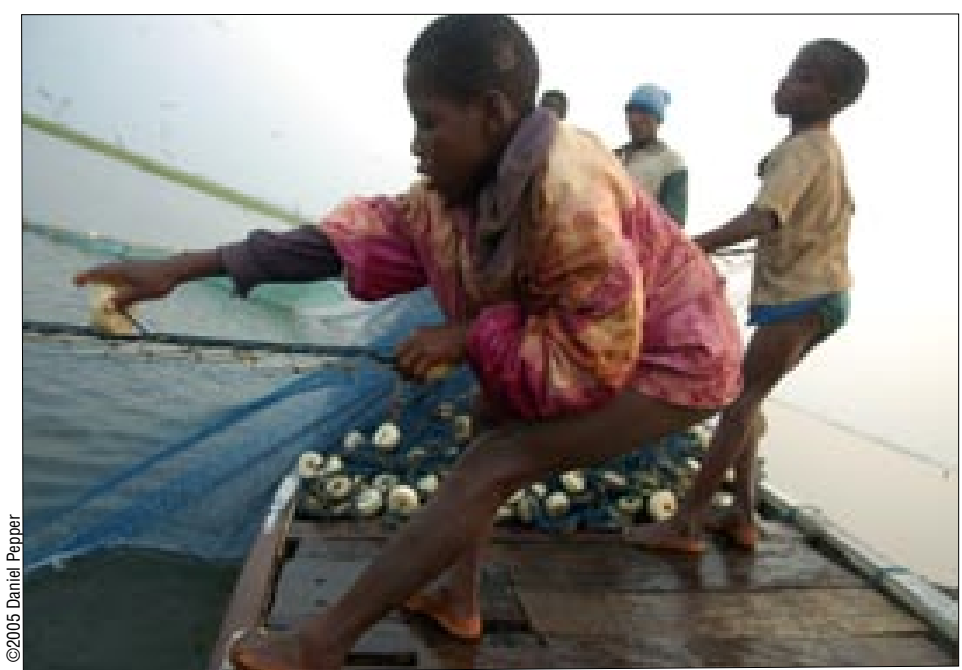

A trafficked Ghanaian child, one of thousands forced to work seven days a week, fishes in Lake Volta, Ghana. Rural children are either sold by their parents or exchanged for money, an agreement that is generally brokered by the fishing recruiters.

\section{The Causes of Labor} Trafficking

Most instances of forced labor occur as unscrupulous employers take advantage of gaps in law enforcement to exploit vulnerable workers. These workers are made more vulnerable to forced labor practices because of unemployment, poverty, crime, discrimination, corruption, political conflict, and cultural acceptance of the practice. Immigrants are particularly

vulnerable ${ }^{2}$ but individuals are also often forced into labor in their own countries.

\section{Bonded Labor}

One form of force or coercion is the use of a bond, or debt, to keep a person in subjugation. This is referred to in law and policy as "bonded labor" or "debt bondage." It is criminalized under U.S. law and included as a form of exploitation related to trafficking in the United Nations protocol on trafficking in persons. Many workers around the world fall victim to debt bondage when they assume an initial debt as part of the terms of employment, or inherit debt in more traditional systems of bonded labor. In South Asia, this phenomenon exists in huge numbers as traditional bonded labor in which people are enslaved from generation to generation.

\section{Involuntary Servitude}

People become trapped in involuntary servitude when they believe an attempted escape from their conditions would result in serious physical harm or the use of legal coercion, such as the threat of deportation. Victims are often economic migrants and low-skilled laborers who are trafficked from less developed communities to more prosperous and developed places. Many victims experience physical and verbal abuse, breach of an 
employment contract, and may perceive themselves to be in captivity — and too often they are.

\section{Domestic Servitude}

Domestic workers may be trapped in servitude through the use of force or coercion, such as physical (including sexual) or emotional abuse. Children are particularly vulnerable to domestic servitude which occurs in private homes, and is often unregulated by public authorities. For example, there is great demand in some wealthier countries of Asia and the Persian Gulf for domestic servants who sometimes fall victim to conditions of involuntary servitude.

\section{Child Labor}

Most international organizations and national laws indicate that children may legally engage in light work. ${ }^{3}$ By contrast, the worst forms of child labor are being targeted for eradication by nations across the globe. The sale and trafficking of children and their entrapment in bonded and forced labor are particularly hazardous types of child labor. Forced conscription into armed conflict is another brutal practice affecting children, as armed militias recruit some children by kidnapping, threat, and promise of survival in warravaged areas.

\section{What Consequences Do Victims Face?}

Victims of trafficking for forced labor lose their freedom, becoming modern-day slaves. They experience permanent physical and psychological harm, isolation from families and communities, reduced opportunities for personal development, and restricted movement. ${ }^{4}$ Victims are often wary of law enforcement and psychologically dependent on their traffickers. Child victims are denied educational access, which reinforces the cycle of poverty and illiteracy.

\section{What is the United States doing to combat human trafficking for forced labor?}

The 2000 Trafficking Victims Protection Act and 2003 Trafficking Victims Protection Reauthorization Act mandates efforts to combat trafficking in persons.

- The Department of State issues an annual Trafficking in Persons Report that assesses foreign government actions to combat trafficking, including prevention, protecting the victims of labor servitude and punishing their exploiters. The 2005 Trafficking in Persons Report includes an increased number of countries on Tier 3 for labor violations.

- Four countries were placed on Tier 3 in 2005 for insufficient efforts to take action to comply with U.S. standards for the elimination of trafficking, including the exploitation of some workers: Kuwait, Qatar, Saudi Arabia, and the United Arab Emirates.

- Burma, North Korea, Sudan and Cuba remain on Tier 3 largely because of their lack of efforts to address forced labor in their countries.

- The Trade and Development Act of 2000 mandates efforts to eliminate the worst forms of child labor including the trafficking of children and forced child labor, as a criterion for countries receiving trade benefits.

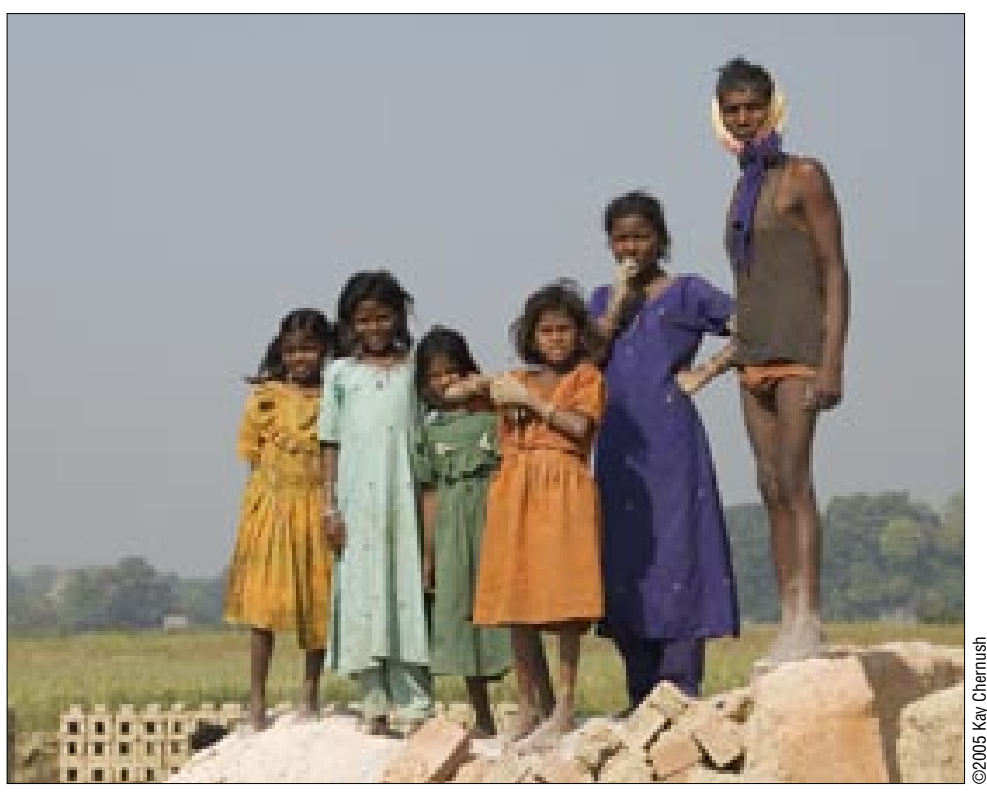

A family in rural South Asia, bonded into slavery for generations.

The Department of Labor (DOL) produces an annual report on the steps countries are taking to combat the worst forms of child labor.

- In FY 2004 alone, the United States Government spent more than $\$ 81$ million on anti-trafficking efforts abroad to assist governments and non-governmental organizations. About 24 percent, (\$19.4 million), of that amount focused in part on labor trafficking, while 14 percent $(\$ 11.3$ million) focused primarily on programs to combat labor trafficking. These programs include:

- A partnership between the Department of State and the International Organization for Migration to reintegrate and identify children trafficked into the fishing industry in the Lake Volta region of Ghana.

- A USAID-funded project in Uganda with the International Rescue Committee rehabilitates children who were abducted by a terrorist organization that operates in Southern Sudan and Northern Uganda, and to protect other children from abduction.

- A Department of State-funded project with Free the Slaves in India to free indentured servants, train law enforcement officials, provide counseling to victims, and raise awareness in rural villages.

- A DOL-funded program with Catholic Charities in Brazil to identify trafficking routes, improve coordination between law enforcement and labor inspectors, and train police in to better detect and investigate trafficking for forced labor.

For more information, please log on to the Web site of the State Department's Office to Monitor and Combat Trafficking in Persons at www.state.gov/g/tip.

\footnotetext{
Human Rights Watch Report; "Bad Dreams: Exploitation and Abuse of Migrant Workers in Saudi Arabia" July, 2004. http://hrw.org/mideast/saudi/labor

${ }^{2}$ Tuller, David, 2005. "Freedom Denied: Forced Labor in California." Human Rights Center, University of California Berkeley, pg. 1. www.hrcberkeley.org/download/freedomdenied.pdf 32004 DOL Report on the Worst Forms of Child Labor, pg. xlv-xlvi; International Labour Organization. 1973. Convention concerning Minimum Age for Admission to Employment. No. 138. http://www.ilo.org/ilolex/english/convdisp1.htm.

${ }^{4}$ Tuller. pp. 1 and 4.
} 